Altaid uplifts the site of the Indian Ocean was covered by a continent which extended from South America across the Old World to Australia. This continent, Gondwanaland, was broken up by successive subsidences; and the gulfs thus formed were gradually enlarged by further subsidences and so developed into the Atlantic and two basins of the Indian Ocean. These movements were accompanied by volcanic eruptions which deluged equatorial Africa and western India under floods of lava, while East Africa was torn asunder by the formation of the Great Rift Valley. If these eruptions and fractures were due to the formation of the Indian Ocean, it appeared strange that no corresponding phenomena were known on its eastern side. The evidence, however, is now clear that in Burma and western China there were volcanic eruptions which, though on a smaller scale, agree in date with the three main volcanic periods of East Africa; while meridional fractures of the same date as those which made the Great Rift Valley formed the great basins of Yunnan in western China. These fractures in Asia produced features different in some respects from those of East Africa, owing to the difference in structure between the continents. East Africa is an ancient solid plateau, whereas Yunnan has an extremely complex foundation due to the intersecting mountain folds. The fractures have therefore been less regular and shorter.

The date of the later movements in Chinese Tibet is indicated by the river system. The drainage of southeastern Tibet collects into three rivers which flow for I40 miles on parallel courses through a narrow belt, and instead of joining they then diverge, the Yangtze discharging into the China Sea 2000 miles from the mouth of its neighbour, the Salween. The present river system is the result of a long evolution controlled by the mountain-forming movements. The drainage of central and south-eastern Asia in pre-Himalayan times was probably mainly through broad east to west trending valleys due to a gentle buckling of the earth's crust. The Himalayan movements confirmed this system; but during the subsequent settling down of the country the eastward outlet of the Tibetan rivers was reduced and Tibet became a land of lakes, to an extent even greater than it is now. Their level rose until they found outlets to the south, through lines of weakness along the Altaid grain. The Tibetan rivers through these southern outlets discharged to the South China Sea. The upper Brahmaputra or Tsangpo discharged through the Dihang, crossed the site of Assam, and passed through the Hukong Gap to the Irrawadi. The Tibetan section of the Yangtze Kiang flowed through Tali Lake to the Red River of Tonkin. Further earth movements broke up this system and diverted its western member through the valley of Assam as the Lower Brahmaputra to the Bay of Bengal, and the eastern by a series of deep gorges and striking zigzags across eastern China to the South Pacific.

The geographical relations of the mountains of southeastern Asia therefore indicate that the Alpine-Himalayan System is a crumpled band of the crust, where the in-sinking northern dome of the world pressed against the tropical belt. The east to west ridges on the floors of the North Atlantic and North Pacific may be attributed to the same forces as produced the Alps and the Himalaya; and the east to west trending mountains, of which remnants are the dominant features in the topography of the West Indies and central America, are also an expression of the buckling of the crust of the Northern Hemisphere where the northern dome of the earth meets its tropical and subtropical belt.

\title{
Recent Developments in the Nitrogen-fixation Industry.
}

WHEN the historian of the future writes concerning the influence of scientific discovery and achievement upon civilisation, we may be sure that he will have much to say about the political and economic effects of the development of the nitrogenfixation industry. Of all the material factors that helped to make the War the greatest and most devastating conflict in human history, the possession by the Germans of adequate plant for making synthetic ammonia, and of adequate personnel for working it, was probably the most important. Since that time the processes for fixing atmospheric nitrogen have been further developed, and the present yearly production of fixed nitrogen is approximately 500,000 metric tons, three-quarters of which is made in Germany.

The arc process, the lineal descendant of Cavendish's initial discovery in 1783 , now contributes only a relatively small proportion of the total production, namely, about 36,000 m.t., its high power-requirement rendering it uneconomical save in countries possessing cheap and abundant water-power. The modification of the process involving the use of oxygen-enriched air, which was worked principally in Switzerland and Germany until I92I, had to be abandoned owing to the serious explosions to which it gave rise. The Swiss Nitrum Co., which worked it on a large scale, has recently adopted the Claude process in its stead.
Fixation by means of calcium carbide was developed enormously during the War, but the present outlook for this method is not promising: calcium cyanamide has not come up to expectations as a nitrogenous fertiliser, and the power-requirement, although only about one-fifth that of the arc process, is 3-4 times greater than that of the direct synthetic-ammonia process. The output of cyanamide has declined to about $x 40,000$ m.t. per annum, and about one-half of the world's plant capacity is unutilised. There are, however, still possibilities, for cyanamide can be used as an intermediate product in the manufacture of urea, of ammonia, and of "Ammo-phos," a fertiliser made on a small scale in the United States.

Urea appears to be the nitrogenous fertiliser of the future. It is the most concentrated of its class ; it can be transported and used without difficulty; it leaves neither acid nor alkali behind in the soil ; and it has given general satisfaction in experimental work. It will probably be manufactured by combining synthetic ammonia and carbon dioxide at high temperature and pressure. Since r 922 a combination of urea and acid phosphate, called "Phosphazote" has been made in Switzerland, and a large works in Norway is to start its production early in the current year.

The Haber process and its modifications, involving the direct union of nitrogen (from liquid air) and

$$
\text { NO. } 2891 \text {, VOL. I I } 5]
$$


hydrogen in presence of a catalyst, at various temperatures and pressures, now contribute about 65 per cent. of the world's supply of fixed nitrogen. In this process the cost of producing and purifying the hydrogen is a dominating factor; in Germany it is prepared from water-gas (Bosch process), in France by fractionating coke-oven gas (Claude process), and in Italy by electrolysing water (Casale and Fausser processes). Electrolytic hydrogen is very pure, but its production is only feasible where water-power is cheap. The Casale process is being actively worked in Calabria by a company with a capital of 9 million Swiss francs, and in the United States the Hooker Chemical Co. is so satisfied with its success that it has decided to double its plant at Niagara Falls.

Other important factors in the Haber process are the choice of catalysts and the form of marketing the ammonia. In the Fixed-Nitrogen Research Laboratory of the United States Government, improved catalysts have been made which, it is expected, will reduce the cost of ammonia-production by one-half ; working on a small scale, at 1500 atmospheres pressure, nearly 80 per cent. of a nitrogen-hydrogen mixture was converted during a single passage through the catalyst. Improved catalysts have also been made for the watergas reaction $\left(\mathrm{CO}+\mathrm{H}_{2} \mathrm{O}=\mathrm{H}_{2}+\mathrm{CO}_{2}\right)$. With these and other improvements it is hoped to reduce the price of ammonia to 5-6 cents per $\mathrm{lb}$.

At Billingham-on-Tees, Synthetic Ammonia and Nitrates, Ltd., has started manufacture on a large scale A modified Haber process is used, and the ammonia is fixed by the calcium-sulphate method, which was developed, and is still used, in Germany. It is probable that synthetic ammonia will be used in conjunction with the Solvay soda process, the ammonia being converted into ammonium chloride, which preliminary trials have shown to be comparable with ammonium sulphate in fertilising value.

The Bucher process of fixing nitrogen as cyanide has not fulfilled expectations, but it appears probable that the du Pont Co. will make it a success. Instead of passing nitrogen (at ${ }_{5} \mathrm{lb}$. pressure) over soda ash, coke, and a catalyst, this company uses producer-gas and a mixture of carbon black and soda ash (plus catalyst) obtained by evaporating to dryness the "blatk liquor". which results from boiling wood with caustic soda in the manufacture of wood-pulp, and by heating the residue out of air at $250^{\circ}-35^{\circ} \mathrm{C}$. This mass is very porous, and contains $60-65$ per cent. soda ash and $40-35$ per cent. carbon, mainly colloidal. The yield of cyanide at this stage is $5^{0-55}$ per cent., and the period of heating is only 70 per cent. of that required in the original process. The reaction-product is leached with water, and 96-98 per cent. sodium cyanide is obtained by crystallisation. The carbon monoxide evolved during heating is mixed with producer-gas and burned under the retorts, which are made of very resistant cast. chrome-iron alloy, high in chromium. A valuable decolorising carbon is extracted from the residue after leaching. Cyanide, it may be mentioned, can be decomposed by steam to yield ammonia.

The marvellous growth of the nitrogen-fixation industry has naturally excited those interested in the production of Chilean nitrate, the consumption of which has not advanced pari passu with that of the artificial products; but the processes used in Chile are known to be wasteful, the Chilean Government could reduce the export tax of 50 s. per ton in case of emergency, and the deposits are likely to last much longer than was originally thought probable. In view, however, of the fact that no other nitrate deposits, in any way comparable with those of Chile, have been dis covered, it can only be a question of time-a generation or two-before the synthetic products will hold undisputed sway. It is, of course, possible that means may be found of speeding up nitrification in the soil but even in that event no nation could afford to be without a nitrogen industry for producing explosives. Furthermore, fixed nitrogen is being increasingly used as ammonia for cold-storage plants, as cyanide for gold extraction, and as nitro-cellulose for making celluloid, artificial leather, and similar products. Great developments of the industry may, therefore, be confidently. anticipated.

\section{Obituary.}

\section{The Marquess Curzon of Kedleston, K.G., F.R.S.}

$\mathrm{BY}$ the death of Lord Curzon, Lord President of the Council, and formerly Viceroy of India and Secretary of State for Foreign Affairs, on March 2o, public life in Great Britain has lost one of its most striking personalities. His long and distinguished career in politics had won him high honours in the State; but in a more restricted circle he was held in equal esteem for his scholarship and his efforts to promote those studies with which his interests and pursuits had brought him into touch.

George Nathaniel Curzon, son of Lord Scarsdale, was born on January $x 1,1859$. After a distinguished career at Eton and Oxford, which included the presidential chair of the union and led to a fellowship of All Souls, Mr. Curzon, as he then was, embarked on a political career, entering Parliament in 1887 , first holding office as Under-Secretary of State for India in I891, by which time he was already recognised as an authority on the East. It is unnecessary to enter here into the details of his political career, which are well known. His services to the State were recognised by successive peerages of every grade up to the rank of marquess and the orders of the Garter, the Indian Empire, the Star of India, and the Royal Victorian Order.

Apart from politics, Lord Curzon won distinction as a geographer and student of the peoples of the East. Between 1886 and 1894 he visited India four times and twice travelled round the world. In I 888 he travelled through Asiatic Russia, recording his observations in his book "Russia in Central Asia." He followed this with a book on Persia and the Persians, a comprehensive account and perhaps his most considerable contribution to geographical literature, which later was to have considerable effect on policy in the Middle East and is still a work of authority. This appeared after a journey in Persia as correspondent of the Times in 1889 , in the course of which he travelled more than r6oo miles on horseback and toured the Persian Gulf. A later book, "Problems of the Far East," dealt with conditions in and the prospects of the countries lying 